\title{
Endocrinopathies associated with lithium therapy in an Irish tertiary referral centre
}

Dineen R. ${ }^{1}$, Bogdanet D. ${ }^{1}$, Thompson D. ${ }^{1}$, Thompson $\mathrm{CJ}^{3}$, McKay P. ${ }^{2}$, Boran G. ${ }^{1}$, Gibney J. ${ }^{1}$, $\mathrm{O}^{\prime}$ Keane $\mathrm{V}^{2}$, Sherlock M. ${ }^{1}$

${ }^{1}$ Department of Endocrinology, The Adelaide and Meath incorporating the National Children's Hospital, Tallaght, Dublin, Ireland., ${ }^{2}$ Department of Psychiatry, , The Adelaide and Meath incorporating the National Children's Hospital, Tallaght, Dublin, Ireland.
Beaumont Hospital, Dublin, Ireland.

\section{Introduction}

* Lithium is used in psychiatric practice as maintenance therapy in bipolar disorder.

* It has a narrow therapeutic index with serious toxic potential.

* Lithium is associated with multiple endocrine and metabolic disturbances but data regarding the rates of these in individual patients is lacking.

\section{Aim}

* The aim of this study was to assess the impact of lithium therapy on the development of endocrinopathies.

\section{Method}

* In a tertiary referral centre, all patients on lithium therapy from 2000 to 2014 were identified.

* Electrolyte and metabolic profiles were obtained through the biochemistry laboratory electronic records system.

\begin{tabular}{l} 
Results \\
\hline Population Demographics \\
$* 580$ patients were identified across the 14 year period. \\
$*$ The mean age of the population was 54.8 years $( \pm$ SD 15.69$)$ \\
$* 42 \%$ were female and $58 \%$ were male.
\end{tabular}

Table 1. Analysis of lithium use in the population group

\begin{tabular}{|c|c|}
\hline & Median (+/- SD ) \\
\hline Peak Lithium level (mmol/l) & $0.82(0.45)$ \\
\hline $\begin{array}{c}\text { Duration of therapy } \\
\text { (years) }\end{array}$ & $4.24(6.66)$ \\
\hline No of lithium level checks/ person & $5(11.9)$ \\
\hline $\begin{array}{c}\text { No of patients with toxic lithium levels } \\
\text { (\% of total) }\end{array}$ & 161 \\
\hline
\end{tabular}

Table 2. Analysis of patients with Toxic lithium levels

\begin{tabular}{|l|l|}
\hline $\begin{array}{l}\text { Patients with } \\
\text { Toxic Lithium levels }\end{array}$ & $\begin{array}{l}\text { Frequency }(\mathrm{n}) \\
\text { (\% of group) }\end{array}$ \\
\hline $\begin{array}{l}\text { Hypernatraemia } \\
\text { (serum Na>145mmol/I) }\end{array}$ & $42(26.1 \%)$ \\
\hline $\begin{array}{l}\text { Hyponatraemia } \\
\text { (serum Na<135mmol/l) }\end{array}$ & $53(32.9 \%)$ \\
\hline Impaired renal function & $85(52.8 \%)^{*}$ \\
\hline Hypercalcaemia & $18(11.2 \%)$ \\
\hline
\end{tabular}

${ }^{*} \mathrm{P}$ value $<0.001$
Hypernatraemia among patients receiving Lithium Therapy * In total $16.4 \%$ of patients had one episode of Hypernatraemia * $34(\mathbf{3 6} \%)$ of the patients with $\mathrm{Na}>145$ were inpatients *61 (64\%) of the patients with $\mathrm{Na}>145$ were outpatients

* 29 patients had comparable serum \& urine osmolality samples available.

* 12 /29 had biochemical evidence of nephrogenic diabetes insipidus.

Hyponatraemia among patients receiving Lithium Therapy * In total $\mathbf{2 0 . 3 \%}$ of patients had one episode of Hypernatraemia

* 51 (43\%) of the patients with $\mathrm{Na}<135$ were inpatients

$* 67(57 \%)$ of the patients with $\mathrm{Na}<135$ were outpatients

* 24 patients (4.1\% of total study group) developed both hypo- and hypernatraemia during follow-up.

Table 3. Thyroid Dysfunction in Patients receiving Lithium Therapy

\begin{tabular}{|l|l|l|l|l|} 
& $\begin{array}{l}\text { Patient } \\
\text { Count }\end{array}$ & $\begin{array}{l}\text { \% of } \\
\text { study } \\
\text { population }\end{array}$ & $\begin{array}{l}\text { TPO antibodies } \\
\text { checked }(n)\end{array}$ & $\begin{array}{l}\text { TPO antibody } \\
\text { positive (n) }\end{array}$ \\
\hline TSH $>4.2 \mathrm{mU} / \mathrm{L}$ & 178 & $30.7 \%$ & 59 & 30 \\
\hline TSH $<0.3 \mathrm{mU} / \mathrm{L}$ & 54 & $9.3 \%$ & 12 & 5 \\
\hline
\end{tabular}

\section{Abnormal Calcium Homeostasis in patients receiving Lithium Therapy}

* 503 patients $(86.7 \%)$ had serum calcium measurements

$\bullet 6.4 \%$ of these patients had hypercalcaemia.

* 16 patients had a PTH level.

4 4/16 with elevated PTH also had impaired renal function.

$* 3.8 \%$ of these patients had hypocalcaemia

* 3 patients had a PTH level which were appropriately elevated.

\section{Conclusion}

* Chronic lithium maintenance therapy and impaired renal function were risk factors for toxicity.

* This study highlights the multiple electrolyte and hormone disturbances observed in patients on lithium.

* Clinicians should be aware of this in order to monitor, detect and institute early and appropriate management of endocrinopathies 